\title{
THE DISTINCTION OF THE CONCEPTS «EMOTIONALITY», «EXPRESSIVENESS», AND «EMOTIVENESS» IN MODERN LINGUISTICS
}

\section{Anna Pikalova $^{1}$}

DOI: https://doi.org/10.30525/978-9934-26-050-6-60

In the modern society, a significant part of scientific research is devoted to the place of emotions in human life. Goleman D. recognizes the close interaction between emotions and the mind, between the processes of thinking and the work of senses [15]. The researches of many psychologists, whose theories of emotions are cognitive, are useful for specialists in various branches, since they contain a scientific basis for the interaction of emotional and cognitive human activities (Ellsworth P. \& Smith C. [13], Frijda N.H. [14], Robinson M.D., Watkins E.R., \& Harmon-Jones E. [19] and others).

Emotions are mental states, acts that are manifested in the human mind in the form of experiences, sensual excitement [4, p. 228-229]. According to the dictionary definitions, the concept «emotion» is interpreted as: a strong feeling deriving from one's circumstances, mood, or relationships with others

\footnotetext{
${ }^{1}$ Municipal Establishment «Kharkiv Humanitarian and Pedagogical Academy» Kharkiv Regional Council, Ukraine
} 
[20], a strong feeling such as love, fear, or anger; the part of a person's character that consists of feelings [21], a strong feeling such as love or anger, or strong feelings in general [17].

Despite the intent attention of scientists to the issue of defining emotions and numerous attempts to promote the theory of emotions, there is a difference of opinions in the exploration of emotions. This aspect indicates the relevance of the problem of researching emotions.

Emotions are usually defined as the opposition of rational thoughts and cognition. At the same time, emotions are explanations of people's thoughts based on emotions, what people think and why they think in such way but not in other one [12, p. 170].

In this perspective the question «What is primary: emotions or cognitive processes?» is turned out to be logical.

According to Izard C.E., the interaction of emotion and cognitive processes is characterized by dynamism. This is due to the fact that both emotions can activate cognitive processes and cognitive processes can initiate emotions [16].

Recently, thorough research in psychology has served as a shift in the study of emotions in the linguistics. Scientists are showing a keen interest in the exploration of emotions in the aspect of their correlation with the cognitive processes of the personality. In particular, the researches of the category of emotiveness are intensified [18].

The views of scientists who distinguish the concepts «expressiveness», «emotionality» and «emotiveness» are quite convincing.

Krylova O.A. considers «expressiveness» as strengthening the expression of speech, increasing its power of influence. The researcher points out that the emotionality of speech is the expression of the speaker's feelings and the impact on the listener's feelings [5, p. 85]. Moreover, the term «expressiveness» is determined as «expression» [1, p. 561]. Galperin I.R. suggest an idea of the category of expressiveness as a kind of intensification of the statement [2, p. 22].

Thus, expressiveness is a linguistic category that covers a system of linguistic and stylistic means of the text. It allows to reveal the content of the text more completely, while intensifying the expression of speech.

The concept «emotionality» is considered as a natural, unprepared manifestation of emotions in the process of communication [3]. Maslova V.A. states «emotionality» as a "psychological characteristic of the personality, the state, qualities and the level of the emotional sphere» [7, p. 185].

Thus, emotionality is an explicit expression of emotions aimed at the demonstration of the speaker's true feelings. 
Cherkashyn S.V. emphasizes the synonymy and parallelism of emotionality and emotiveness. However, the researcher does not deny a difference between these concepts and defines emotionality as psychological category whereas emotiveness as linguistic one [9].

Regarding the distinction between the concepts of «emotionality» and «emotiveness», Cowie R. and Cornelius R. distinguish two types of description of emotions in the aspect of speech researches: «cause-type» and «effect-type». Thus, «cause-type» description refers to «internal states and external factors that cause the particular characteristics of a person's speech.» Whereas «effect-type» one describes «what effect particular speech characteristics will have on a typical listener» [11, p. 7-8].

Although the scientists do not determine the distinguished types as «emotionality» and «emotiveness», but, in our opinion, this accurate delineation of the concepts provides a basis for their definition. It becomes clear that what has caused emotions and has reflected in the specific features of speech, it is defined as «emotionality». Whereas «emotiveness» characterizes the influence that certain features of speech have caused on the reader / listener.

Emotiveness is a conscious, planned demonstration of emotions, a special strategy of the speaker's behaviour, which is aimed at the addressee [6, p. 63]. Filimonova O.E. determines the category of emotiveness as a multi-statutory cognitive category that reflects the emotional state of a person. It also has features of representation in different texts [8, p. 6]. Shakhovskyi V.I. expresses the opinion that emotiveness is a special semantic category, the originality of which largely depends on the individuality of its «creator», his life experience and emotional mood [10, p. 69].

Analysis of the scientific papers on the problems of researching expressiveness, emotionality and emotiveness allows us to state the fact that emotiveness is a cognitive-pragmatic category. It is represented through emotions, feelings, worry and excitement in language. Emotiveness actualizes the representation of the addressee's emotions.

Thus, it becomes clear that the linguistics researches of the concepts which are connected with emotions can be efficient supposing an interdisciplinary approach that allows to integrate a wide range of different scientific branches.

\section{References:}

1. Ahmanova, O.S. (2007). Slovar lingvisticheskih terminov [Dictionary of linguistic terms]. Moscow: KomKniga.

2. Galperin, I.R. (1950). Perevod i stilistika [Translation and stylistics]. Moscow: Sb. «Teoriya i metodika uchebnogo perevoda», APN.

3. Hnezdilova, Ya.V. (2007). Emotsiinist ta emotyvnist suchasnoho anhlomovnoho dyskursu: strukturnyi, semantychnyi i prahmatychnyi aspekty [Emotionality and 
emotiveness of modern English discourse: structural, semantic and pragmatic aspects] (PhD Thesis), Kyiv: Kyiv National Linguistic University.

4. Hromiak R.T., Yu.I. Kovaliv, Teremko V.I. (eds.). (2007). Literaturoznavchyi slovnyk-dovidnyk [Literary dictionary-reference book]. Kyiv: Akademiia.

5. Kryilova, O.A. (2006). Lingvisticheskaya stilistika [Linguistic stylistics]. Kn. 1. Teoriya: Ucheb. posobie. Moscow: Vyisshaya shkola.

6. Larina, T.V. (2003). Kategoriya vezhlivosti $v$ angliyskoy $i$ russkoy kulturah [The category of politeness in English and Russian cultures]. Moscow: RUDN.

7. Maslova, V.A. (1991). Parametryi ekspressivnosti teksta [Options of expressiveness of the text]. In V.N. Teliya (Ed.), Chelovecheskiy faktor $v$ yazyike: Yazyikovyie mehanizmyi ekspressivnosti [The human factor in language: Language mechanisms of expressiveness]. Moscow: Nauka, pp. 179-204.

8. Filimonova, O.E. (2001). Kategoriya emotivnosti $v$ angliyskom yazyike (kognitivnyiy i kommunikativnyiy aspektyi) [The category of emotiveness in English (cognitive and communicative aspects)] (D Thesis), St. Petersburg: Russian State Pedagogical University named after A.I. Herzen.

9. Cherkashyn, S.V. (2008). Doslidzhennia poniattia emotsiinosti khudozhnoho dyskursu $v$ suchasnii linhvistytsi $v$ aspekti kohnityvno-prahmatychnoi paradyhmy [Research of the concept of emotionality of artistic discourse in modern linguistics in the aspect of cognitive-pragmatic paradigm]. Retrieved from: http://www.nbuv.gov.ua/ portal/soc_gum/znpkhnpu/Lingv/2008_25/26.html

10. Shahovskiy, V.I., Sorokin, Yu.A., Tomasheva, I.V. (1998). Tekst i ego kognitivno-emotivnyie metamorfozyi (mezhkulturnoe ponimanie i lingvoekologiya) [Text and its cognitive-emotive metamorphoses (intercultural understanding and linguoecology)]. Volgograd: Peremena.

11. Cowie, R., \& Cornelius, R.R. (2003). Describing the emotional states that are expressed in speech. Speech Communication, 40, 5-32.

12. Edwards, D. (1997). Discourse and cognition. London: Sage.

13. Ellsworth, P., \& Smith, C. (1988). From appraisal to emotion: Differences among unpleasant feelings. Motivation and Emotion, 12(3), 271-302.

14. Frijda, N.H. (2007). The laws of emotion. Lawrence Erlbaum Associates.

15. Goleman, D. (1997). Emotional intelligence. Why it can matter more than IQ. New York; London: Bantam Books.

16. Izard, C.E. (1991). The psychology of emotions. New York: Plenum.

17. McIntosh, C. (Ed.). (2013). Cambridge advanced learner's dictionary (4th ed.). Cambridge: Cambridge University Press.

18. Ptaszynski, M., Dybala, P., Shi, W.H., Rzepka, R., \& Araki, K. (2007). Lexical Analysis of Emotiveness in Utterances for Automatic Joke Generation. ITE Technical Report, vol. 32, no. 47, 39-42.

19. Robinson, M.D., Watkins, E.R., \&Harmon-Jones, E. (Eds.) (2013). Handbook of cognition and emotion. N.Y.; London: The Guilford Press.

20. Stevenson, A. (Ed.) (2010). Oxford dictionary of English (3rd ed.). Oxford: Oxford University Press.

21. Turnbul, J. (Ed.) (2011). Oxford advanced learner's dictionary (8th ed.). Oxford: Oxford University Press. 